\title{
Effect of propofol on cardiac function and gene expression after ischemic-reperfusion in isolated rat heart
}

\author{
Youn Jin Kim, Hae Ja Lim*, and Sung Uk Choi* \\ Department of Anesthesiology and Pain Medicine, School of Medicine, Ewha Womans University, *College of Medicine, Korea \\ University, Seoul, Korea
}

Background: The aim of this study was to examine the cardiac function and transcriptional response of the heart to propofol after ischemia-reperfusion.

Methods: Rat hearts were Langendorff-perfused using the modified Krebs-Henseleit buffer, and took 20 min stabilizing periods, $40 \mathrm{~min}$ ischemia periods, and then $120 \mathrm{~min}$ reperfusion period. The hearts were divided into 5 groups; Control: $180 \mathrm{~min}$ perfusion after stabilization, Ischemic: $40 \mathrm{~min}$ global ischemia after stabilization, followed by 120 min reperfusion, Pre: $2 \mu \mathrm{M}$ propofol treatment was preformed only before ischemia, Post: $2 \mu \mathrm{M}$ propofol treatment was performed only during reperfusion after ischemia, Pre/Post: $2 \mu \mathrm{M}$ propofol treatment was performed both before and after ischemia. The measurement for cardiac performances, such as left ventricular developed pressure (LVDP), rate of left ventricular pressure generation ( $\mathrm{dP} / \mathrm{dt}$ ), heart rate, and coronary flow were obtained. The expression profiles of isolated mRNA were determined by using Agilent microarray and real time-polymerase chain reaction (RT-PCR) was used to confirm the microarray results for a subset of genes.

Results: The Post group showed better LVDP and dP/dt than the Ischemic group. But there were no significant differences in heart rate and coronary flow among the groups. On the results of RT-PCR, the expressions of Abcc9, Bard1, and Casp4 were increased, but the expressions of Lyz, Casp8, and Timpl were decreased in the Post group compared with the Ischemic group.

Conclusions: This study suggests that $2 \mu \mathrm{M}$ propofol may provide cardioprotective effect, and modulate gene expression such as apoptosis, and $\mathrm{K}_{\text {АтP }}$ ion channel related-genes during reperfusion in the isolated rat hearts. (Korean J Anesthesiol 2010; 58: 153-161)

Key Words: Ischemia, Microarray, Propofol, Rat heart, Real time-polymerase chain reaction, Reperfusion.

\footnotetext{
Received: June 29, 2009. Accepted: September 14, 2009.

Corresponding author: Hae Ja Lim, M.D., Department of Anesthesiology and Pain Medicine, College of Medcine, Korea Univesity, 126-1, Anamdong 5-ga, Seongbuk-gu, Seoul 136-705, Korea. Tel: 82-2-920-5632, 82-2-920-5306, Fax: 82-2-928-2275, E-mail: drlimhj@korea.ac.kr This paper is a doctoral dissertation.

(c)This is an open-access article distributed under the terms of the Creative Commons Attribution Non-Commercial License (http:// creativecommons.org/licenses/by-nc/3.0/), which permits unrestricted non-commercial use, distribution, and reproduction in any medium, provided the original work is properly cited.
} 


\section{Introduction}

Reactive oxygen species (ROS) such, as superoxide anions, hydroxyl radicals, and hydrogen peroxide, which are generated after ischemia/reperfusion injuries, play an important role in reperfusion injuries, including myocardiac stunning, cardiac death, dysrrhythmia, and chronic cardiac disease. ROS are now known to induce apoptosis and activate guanylate cyclase and transcriptional factors that act as secondary messengers, both mechanisms which result in cardiac cell death. Therefore, cardioprotective strategies aimed at alleviating or preventing ROS production may be targeted during the ischemia/ reperfusion of cardiac surgery [1-4].

Propofol, which is frequently used in cardiac anesthesia, has a chemical structure similar to phenol-based free radical scavengers such as vitamin $\mathrm{E}$, a scavenger that is responsible for antioxidant activity. The cardioprotective effects of propofol are still debated and unclear. Some previous in vivo/vitro studies have suggested that propofol, when not administered during reperfusion and before the ischemic period, has protective effects $[5,6]$. However, in some clinical studies, different results showed that propofol, when given only during reperfusion, had cardioprotective effects. Various mechanisms to support these findings are: the reduction of free radicals $[7,8]$, the inhibition of the myocardial calcium influx [9], and the suppression of neutrophil activity [10]. However, Ebel et al. did not provide a description of the cardioprotective effects of propofol when administered during reperfusion [11].

DNA microarrays are a powerful genetic technology that can be used to measure changes in expression levels, detect single nucleotide polymorphisms (SNPs), and genotype or resequence mutant genomes. Therefore, arrays have overcome the limited information obtained by southern or northern methods, dramatically accelerated many types of investigations, and have been expected to explore the key cellular events in ischemia/ reperfusion injury and preconditioning. Investigations of ischemic preconditioning effects on the gene expression patterns in rat hearts demonstrated that a number of genes with significantly altered gene expression were significantly altered; however, very little is known about the effects of propofol on the gene expression patterns after ischemic-reperfusion in isolated rat hearts $[12,13]$.

The aim of this study was to examine the cardiac function and transcriptional response of the heart to propofol after ischemiareperfusion.

\section{Materials and Methods}

The study was performed in accordance with the IACUC (Institutional Animal Care and Use Committee) of Korea
University. Male Sprague-Dawley rats (250-300 g: Charles River Laboratory Inc., Tokyo, Japan) were first anesthetized with ketamine $10 \mathrm{mg} / 100 \mathrm{~g}$ followed by an intraperioneal hepariniziation of the hearts with 1,000 IU of heparin. Each heart was quickly removed and perfused in the Langendorff perfusion system (Hugo-Sachs Electronik, March-Hugstetten, Germany). Retrograde perfusion was initiated with modified Krebs-Henseleit buffer, which was saturated with $95 \% \mathrm{O}_{2}-5 \%$ $\mathrm{CO}_{2}$ and contained the following ingredients: $\mathrm{NaCl} 118 \mathrm{mM}$, $\mathrm{KCl} 4.7 \mathrm{mM}, \mathrm{MgSO}_{4} 1.64 \mathrm{mM}, \mathrm{KH}_{2} \mathrm{PO}_{4} 1.18 \mathrm{mM}, \mathrm{NaHCO}_{3} 24.88$ $\mathrm{mM}$, glucose $5.55 \mathrm{mM}, \mathrm{CaCl}_{2} 2.52 \mathrm{mM}$, Na-EDTA $0.5 \mathrm{mM}$. All of the hearts were perfused at a constant pressure of $60 \mathrm{mmHg}$. The $\mathrm{pH}$ and temperature of the inflow were maintained at $\mathrm{pH}=$ $7.4 \pm 0.22$ and $37 \pm 0.2^{\circ} \mathrm{C}$ respectively using a circulating water bath system (Jeio Tech, Model WBC 1520A). A warm distilled water-filled, balloon-tipped catheter with an external diameter of $3 \mathrm{~mm}$ was inserted into the left ventricle through the left atrium. Left-ventricular end-diastolic pressure was adjusted to 5-10 mmHg by adjusting the balloon volume. Coronary flow was measured using collected coronary sinus effluent that was collected from the pulmonary artery cannula. The distal end of the catheter was connected to a performance analyzer (Grass Model No. 79 Polygraph; Grass Instrument Division, AstroMed, West Warwick, RI, USA) using a pressure transducer. To determine the left ventricular developed pressure (LVDP), the maximum and minimum values of the rate of the left ventricular pressure generation $(\mathrm{dP} / \mathrm{dt})$, heart rate, and coronary flow continued to be simultaneously recorded using software (Acknowledge program for windows version 3.5.2, Biopac system Inc., USA).

Animals were randomized into the following 5 groups after equilibration for $20 \mathrm{~min}$ stabilizing periods: Control, $180 \mathrm{~min}$ perfusion after stabilization; Ischemic, 40 min global ischemia after stabilization, followed by 120 min reperfusion; Pre, $2 \mu \mathrm{M}$ propofol treatment was preformed only before ischemia; Post, $2 \mu \mathrm{M}$ propofol treatment was performed only during reperfusion after ischemia; Pre/Post, $2 \mu \mathrm{M}$ propofol treatment was performed both before and after ischemia. Left ventricular developed pressure (LVDP), maximum and minimum rate values for the left ventricular pressure generation $\left(\mathrm{dP} / \mathrm{dt}_{\max }\right.$, $\mathrm{dP} / \mathrm{dt}_{\text {min }}$ ), heart rate, and coronary flow were measured and compared after a reperfusion period of $120 \mathrm{~min}$.

After the protocols were completed, the left ventricular tissue was quickly frozen in liquid nitrogen and stored in RNAlater ${ }^{\circledR}$ (Ambion ${ }^{\circledR}$ Foster City, CA, USA) at $-80^{\circ} \mathrm{C}$. Frozen heart tissue was powdered and homogenized twice using a rotator-stator and a $23 \mathrm{G}$ needle after adding $1 \mathrm{ml}$ of TRIzol (Invitrogen, USA) and vortexing for about $15 \mathrm{sec}$. Residual protein was removed with chloroform $(200 \mu \mathrm{g})$, mixed, vortexed, placed at room temperature for $2 \mathrm{~min}$, and centrifuged for $15 \mathrm{~min}$ at 14,000 rpm 
and $4^{\circ} \mathrm{C}$. The supernatant aqueous phase was precipitated in the same volume of binding buffer by vortexing 10 times followed by an incubation at room temperature for $10 \mathrm{~min}$ and then centrifuging for $10 \mathrm{~min}$ at $14,000 \mathrm{rpm}$ and $4^{\circ} \mathrm{C}$. The RNA pellet was finally extracted by adding $75 \%$ ethanol-treated DEPC and centrifuging for $5 \mathrm{~min}$ at $10,000 \mathrm{rpm}$ and $4^{\circ} \mathrm{C}$. The total RNA was extracted after removing the ethanol, the pellet was dried at room air temperature, and dissolved in RNase-free water. The resulting total RNA pellet was dissolved in ultra pure water and the sample quantity $(260 \mathrm{~nm})$ and quality $(280 \mathrm{~nm})$ were measured by a spectrophotometer. The purification and quality of the total RNA was $2.0 \pm 0.1$ of the $260 / 280$ ratio and more than 1.9 of the $(28 \mathrm{~s} / 18 \mathrm{~s})$ rRNA ratio as measured using the Agilent 2100 Bioanalyzer (Agilent Technology, USA), respectively. cDNA was synthesized from the total RNA with the HighCapacity cDNA reverse transcription kit (Applied Biosystems,
USA). Real time-polymerase chain reaction (RT-PCR), by which gene expressions were quantified, was performed with the SYBR Green I protocol (Takara, Japan) according to the manufacturer's instructions. PCR cycling conditions were performed in a total volume of $20 \mu \mathrm{g}$, after incubation for $5 \mathrm{~min}$ at $70^{\circ} \mathrm{C}$, and cooling for $1 \mathrm{~min}$. The used primer sequences were listed in Table 1, 2.

All values are expressed as the mean \pm SD or SE. SPSS (ver. 13.0) was used for the statistical analysis. Cardiac function, coronary flow, and signal intensities of individual transcripts from the microarray were confirmed by RT-PCR and were compared among groups by one-way ANOVA, followed by Turkey's test for multiple comparisons. Cardiac function and coronary flow were compared between groups using a paired $t$ test. Statistical significance was established at $\mathrm{P}$ values $<0.05$.

Table 1. Biologic Function of Primers used for Quantitative Real Time-Polymerase Chain Reactions

\begin{tabular}{|c|c|c|}
\hline Gene symbol & & Biologic \& molecular function \\
\hline Casp8 & Caspase-8 & Apoptosis, macrophage differentiation \\
\hline Birc3 & Inhibitor of apoptosis protein 1 & Anti-apoptosis \\
\hline Timp1 & $\begin{array}{l}\text { Tissue inhibitor of } \\
\text { metalloproteinase } 1\end{array}$ & Metalloendopeptidase inhibitor activity \\
\hline Casp4 & Caspase-11 & Apoptosis, caspase activation, inflammatory response, proteolysis \\
\hline Lyz & Lysozyme & $\begin{array}{l}\text { Cell wall catabolism, carbohydrate } \\
\text { Metabolism }\end{array}$ \\
\hline Bard1 & BRCA 1 associated ring domain 1 & Transcription factor activity, DNA binding; RNA binding,; zinc ion binding \\
\hline Abcc9 & $\begin{array}{l}\text { ATP-binding cassette, sub-family } \\
\mathrm{C} \text { (CFTR/MRP), member } 9\end{array}$ & $\begin{array}{l}\text { Potassium ion transport, ATP binding, ATPase activity, ATPase activity coupled } \\
\text { to transmembrane movement of substances, receptor activity, sulfonylurea } \\
\text { receptor activity }\end{array}$ \\
\hline Gna11 & $\begin{array}{l}\text { Guanine nucleotide binding protein, } \\
\text { alpha } 11\end{array}$ & G-protein coupled receptor protein signaling pathway, signal transduction \\
\hline Itgal & Integrin alpha 1 & Cell adhesion, cell-matrix adhesion, receptor activity, magnesium ion binding \\
\hline Slick & $\begin{array}{l}\text { Sodium- \& chloride- activated ATP- } \\
\text { sensitive potassium channel }\end{array}$ & ATP binding, intracellular sodium activated potassium channel activity \\
\hline
\end{tabular}

Table 2. Primers Sequence used for Quantitative Real Time-Polymerase Chain Reactions

\begin{tabular}{cl}
\hline Gene symbol & Primer sequence \\
\hline Casp8 & GAACATGGGAAAGCAGATGCCACAGCCCATCTTCACACTACGGAAGAAGCTCTTCTTCCCTCCTAACTGA \\
Birc3 & CGTAAAACAGAAACCACACACCTTGCAGGCAAGGACACTGATCGATACTGTATTAGCGAAAGGAAACACC \\
Timp1 & TTCATGGGTTCCCCAGAAATCATCGAGACCACCTTATACCAGCGTTATGAGATCAAGATGACTAAGATGC \\
Casp4 & AAGTATTAATTCCCAGATGCCCACCATTGATCGGGCAACCTTGACAAGATATTTCTACCTCTTTCCTGGC \\
Lyz & GCTGCAGGATGACATCACTCAAGCCATACAATGTGCGAAGAGAGTTGTGAGGGATCCCCAAGGCATTCGA \\
Bard1 & GGCGCGTGGTTTGTGAGAACACGGCCATTGTGATGTTTGATCACTCTCGCTTTTATGGATAGGTAGAACC \\
Abcc9 & CCTTCGACTGTCTACTTCTAACCTATCCATGGGCGAGATGACCCTGGGACAGATCAACAACTTGGTTGCC \\
Gnal1 & GACTTTTGAGCATCAGTATGTGAACGCCATCAAGACACTGTGGAGTGACCCTGGTGTCCAGGAGTGCTAC \\
Itgal & GTAGACCCCGGAGCCTTGAGGACCCCTTTGGCATCAACTCTGGGAAGAAAATGACAATATCGAAGTCTGA \\
Slick & GCAGTCACCTGAACAGTGGCAGAAGACGTATGGGAGGTGCTCAGGAAATGAAGTCTACCACATCGTTCTG \\
\hline
\end{tabular}




\section{Results}

Under baseline conditions, the hemodynamic variables were similar in all groups. Fig. 1 shows coronary flow, left ventricular developed pressure (LVDP), $\mathrm{dP} / \mathrm{dt}_{\text {max }}, \mathrm{dP} / \mathrm{dt}_{\text {min }}$ measured at baseline and immediately after the 120 min reperfusion period in isolated rat hearts. In left ventricular developed pressure (LVDP), $\mathrm{dP} / \mathrm{dt}_{\text {max }}, \mathrm{dP} / \mathrm{dt}_{\text {min }}$, we found a significant difference in the Post group compared with the Ischemic group $(\mathrm{P}<0.05)$. Coronary flow that developed during the baseline and reperfusion periods in the isolated rat hearts was
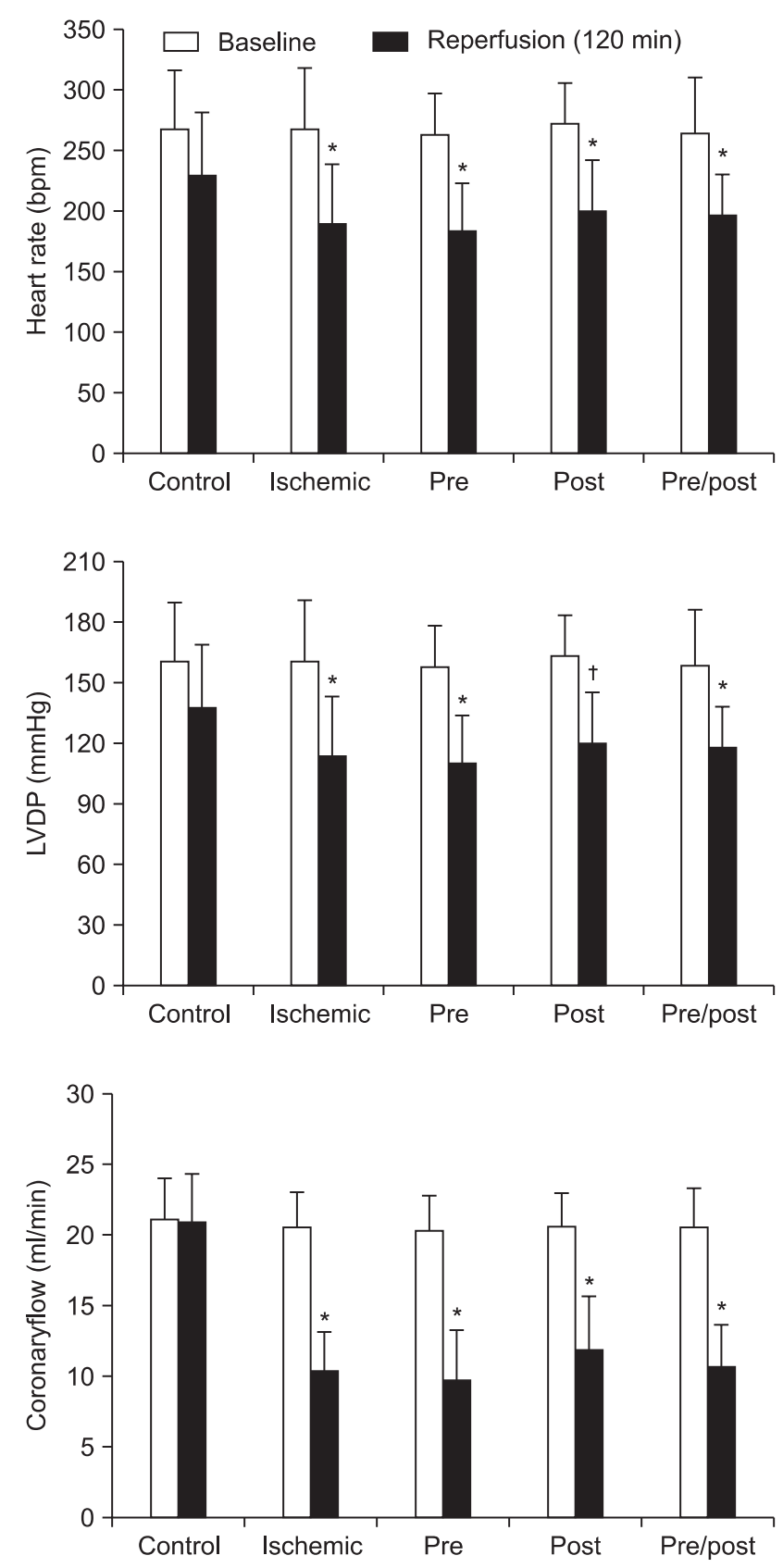

not significantly different among the groups. One of the Post groups has increased values compared with one of the Ischemic and Pre groups, but we found no significant difference among the groups. The heart rate that developed during baseline and reperfusion period in the isolated rat hearts was not significantly different among the groups. In contrast, heart rate during reperfusion was significantly decreased compared with its respective baseline values between all groups $(\mathrm{P}<0.05)$. LVDP in the Post groups was significantly increased compared with the Ischemic group (142.6 $\mathrm{mmHg}$ vs $101.2 \mathrm{mmHg}$ ). LVDP in the Ischemic, Pre, and Pre/Post groups, but not the Post
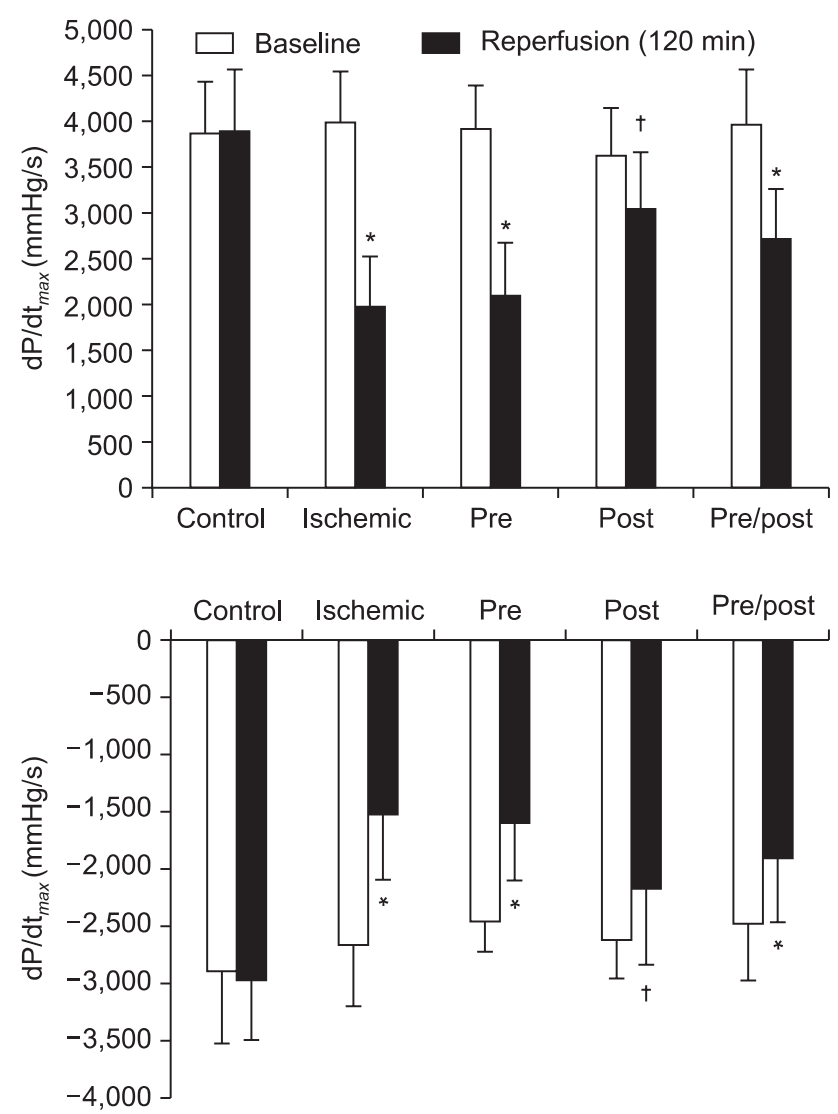

Fig. 1. Heart rate, left ventricular developed pressure (LVDP), coronary flow, $\mathrm{dP} / \mathrm{dt}_{\text {max }}, \mathrm{dP} / \mathrm{dt}_{\text {min }}$ measured at baseline and immediately after $120 \mathrm{~min}$ reperfusion period in the isolated rat hearts. There is a significant difference in the Post group compared with the Ischemic group. The values are mean \pm SD. Control: $180 \mathrm{~min}$ perfusion after stabilization, Ischemic: $40 \mathrm{~min}$ global ischemia after stabilization, followed by 120 min reperfusion, Pre: propofol treatment was preformed only before ischemia, Post: propofol treatment was performed only during reperfusion after ischemia, Pre/post: propofol treatment was performed both before and after ischemia. *Significantly different from its respective baseline value $(\mathrm{P}<0.05)$, ${ }^{\dagger}$ Significantly different from the Ischemic group $(\mathrm{P}<0.05)$. 
group during reperfusion was significantly decreased. We found that the rate of the left ventricular pressure generation, which represents $\mathrm{dP} / \mathrm{dt}_{\text {max }}$ for myocardiac systolic function and $\mathrm{dP} / \mathrm{dt}_{\text {min }}$ for myocardiac diastolic function, was significantly different in the Post group $\left(\mathrm{dP} / \mathrm{dt}_{\text {max }} ; 2,000.9 \mathrm{mmHg} / \mathrm{s}, \mathrm{dP} /\right.$ $\mathrm{dt}_{\text {min }} ;-1,534.6 \mathrm{mmHg} / \mathrm{s}$ ) compared with the Ischemic group

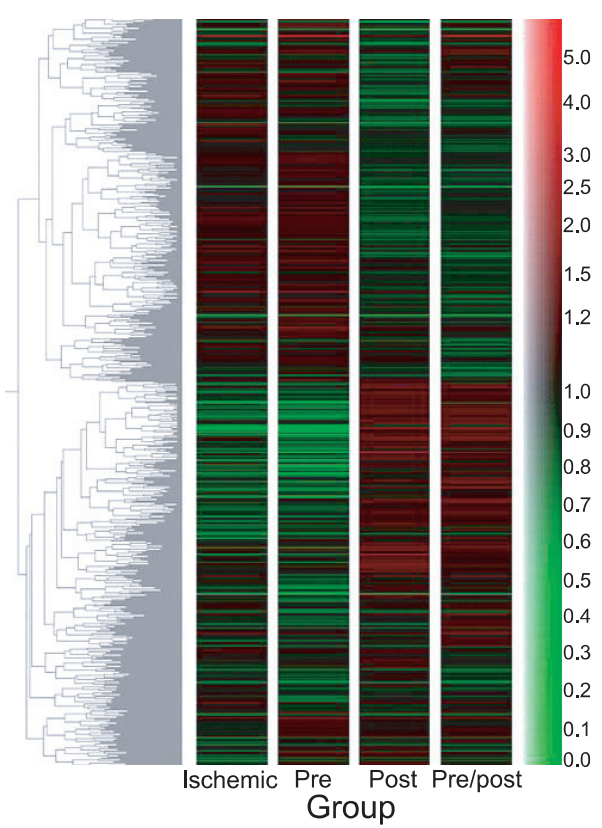

Fig. 2. Total experiments hierarchical clustering. The upper panel demonstrates up-regulated genes (red) compared with the Timematched control group, whereas the lower panel shows downregulated genes (green) compared with the Time-matched control group. Ischemic: $40 \mathrm{~min}$ global ischemia after stabilization, followed by 120 min reperfusion, Pre: propofol treatment was performed only before ischemia, Post: propofol treatment was performed only during reperfusion after ischemia, Pre/post: propofol treatment was performed both before and after ischemia.
$\left(\mathrm{dP} / \mathrm{dt}_{\text {max }} ; 3,060.2 \mathrm{mmHg} / \mathrm{s}, \mathrm{dP} / \mathrm{dt}_{\text {min }} ;-2,175.6 \mathrm{mmHg} / \mathrm{s}\right)(\mathrm{P}$ $<0.05$ ). Finally, we found that the $\mathrm{dP} / \mathrm{dt}_{\max }$ and $\mathrm{dP} / \mathrm{dt}_{\text {min }}$ that developed during the baseline and reperfusion periods was not significantly different among the groups except for in the Post group.

Fig. 2 shows the hierarchical clustering of the total experiments. The Ischemic group contains up-regulated genes (red) in the upper panel, whereas down-regulated genes (green) are located in the lower panel, compared with the Timematched control group.

With regard to the microarray results, Table 3, 4 demonstrate that the Ischemic group up-regulated 1864 genes by 2.0 fold or greater. These genes are composed of about 509 genes that are related to cell proliferation and response to external stimuli, whereas 1350 genes were down-regulated from the Pre group by 2.0 fold or greater, a finding that shows similar gene expression patterns with the Ischemic group. When the Post group was compared with the Time-matched control group, 1994 genes were up-regulated by 2.0 fold or greater. This group is composed of genes related to ion transport and cell communication, whereas 998 genes were down-regulated by 2.0 fold or greater, which were related to apoptosis, the protein kinase cascade, and cytokine production. All genes that had significantly different expression between the Post and Ischemic groups with regard to cardiac functional parameters were assesses by RT-PCR using 10 primers, except for the Slick and Gnall genes. Specifically, the Abcc 9 gene that is related to the $K_{\text {ATP }}$ ion channel was significantly increased, and the Lyz gene is significantly decreased compared to the Abcc 9, Itga 1, Lyz, and Birc 3 genes, which were up-regulated in the Post group by 2.0 fold or greater $(\mathrm{P}<0.05)$. In addition, the Bard1 and Casp4 genes are significantly increased, while the Casp8 and Timpl genes are significantly decreased compared to the

Table 3. Biologic Function of Genes with Increased Expression in Response to Propofol during Reperfusion as Compared with Time-matched Control Group

\begin{tabular}{clcl}
\hline $\begin{array}{c}\text { No. } \\
\text { of genes }\end{array}$ & \multicolumn{1}{c}{ Function/description } & $\begin{array}{c}\text { No. } \\
\text { of genes }\end{array}$ & Function/description \\
\hline Cell growth (13) & & Ion channel (6) & Calcium channel, glutamate receptor, ionotropic \\
3 & Intracellular signal transduction & 1 & Calcium channel, voltage-dependent, L type \\
1 & Angiogenesis & 2 & Potassium channel, inwardly-rectifying channel \\
3 & Ion transport & 1 & ATP-sensitive potassium channel \\
2 & Cytoskeleton organization and biogenesis & 2 & Carbohydrate metabolism \\
2 & AHNAK nucleoprotein & & Cetabolism (10) \\
2 & Others & 1 & Adhesion \\
Defense immunino acid metabolism & & Regulation of fatty acid metabolism \\
1 & Response to oxidative stress & 3 & Others \\
\hline
\end{tabular}


Table 4. Biologic Function of Genes with Decreased Expression in Response to Propofol during Reperfusion as Compared with Time-matched Control Group

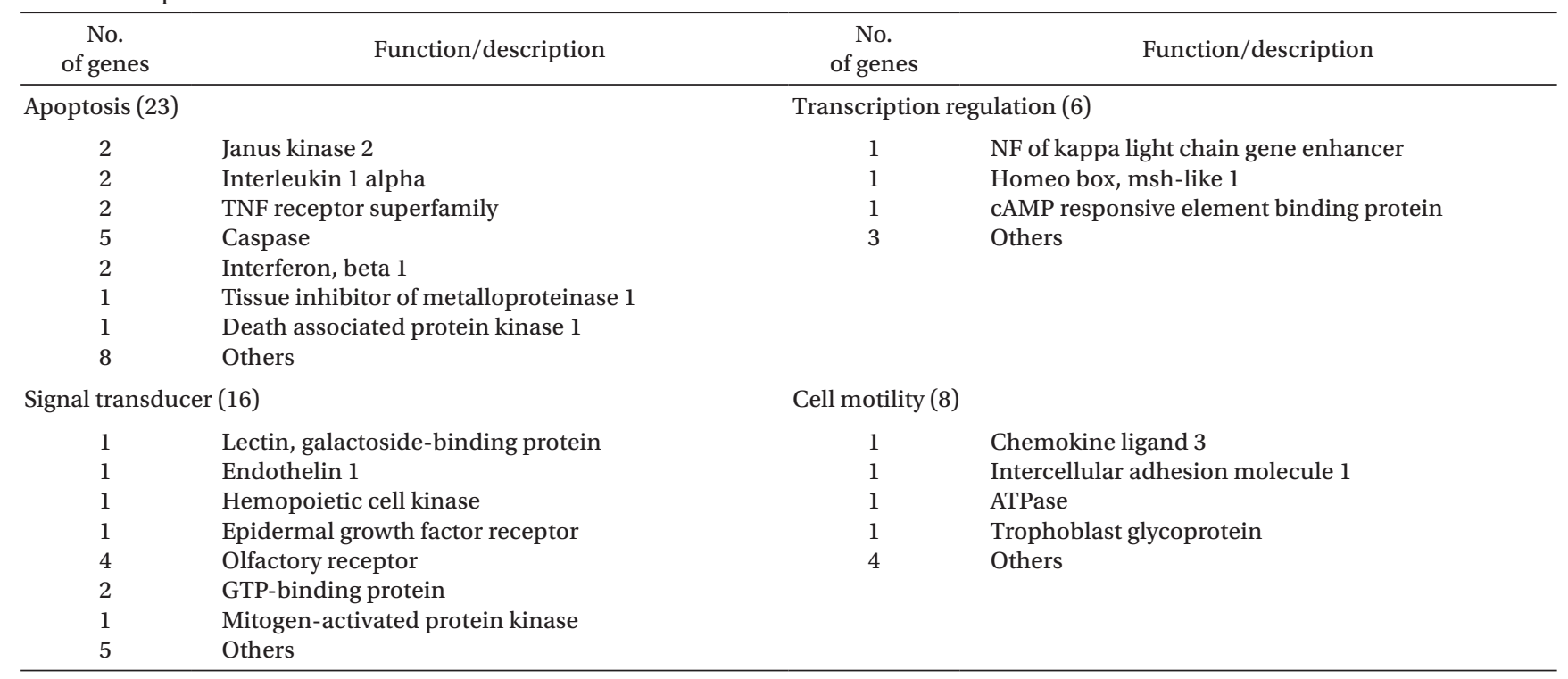

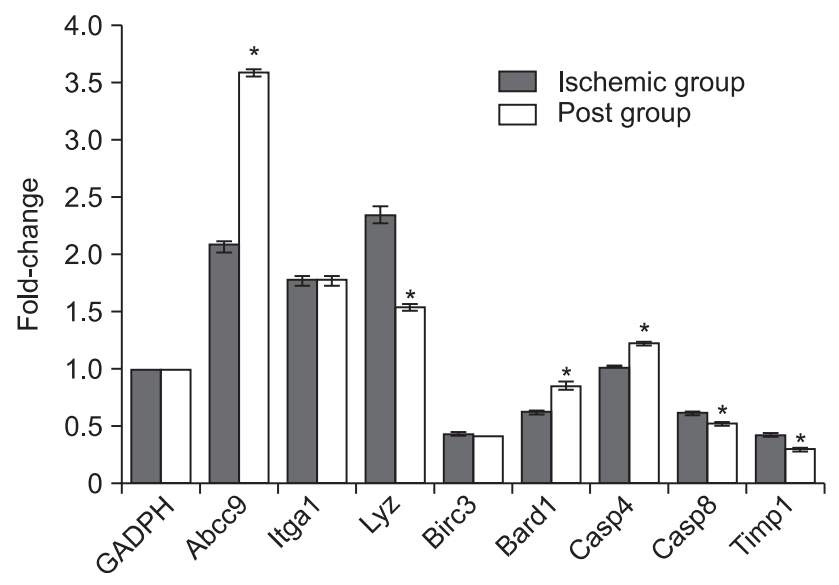

Fig. 3. Confirmation of microarray by means of real time-polymerase chain reactions (RT-PCR) in the Post group compared with the Ischemic group. The two genes of 10 primers, which were undetectable in RT-PCR, were excluded. GADPH was used to normalize mRNA levels. Data are presented as mean $\pm \mathrm{SE}$ ( $\mathrm{n}=3$ for each groups). Abcc9: ATP-binding cassette, sub-family C (CFTR/MRP), member 9, Itga1: integrin alpha 1, Lyz: lysozyme, Birc3: inhibitor of apoptosis protein 1, Bard1: BRCA 1 associated ring domain 1, Timpl: tissue inhibitor of metalloproteinase, Casp4: caspase-11, Casp8: caspase-8. *Significantly different from the Ischemic group $(\mathrm{P}<0.05)$.

Bard1, Casp4, and Timp1 genes, which were down-regulated in Post group by 2.0 fold or greater (Fig. $3, \mathrm{P}<0.05$ ).

\section{Discussion}

We looked into the effect propofol has on gene expression and the function of a Langendorff heart in a Sprague-Dawley rat with an ischemia-reperfusion injury. As a result, in comparison with the Ischemic group, the Post group dosed with $2 \mu \mathrm{M}$ propofol during reperfusion showed excellent results in myocardial function and in the different aspects of gene expression.

In this study, as an indicator of myocardial function for an ischemia-reperfusion injury of propofol, we observed that the left ventricular developed pressure and we also noted the minimum and maximum rate of change of left ventricular pressure. As a result of the experiment, there has been an improvement of systolic dysfunction examined through left ventricular-developed pressure and the maximum rate of change of left ventricular pressure in the Post group dosed of propofol in the reperfusion interval. It also showed a significant improvement in Post group, compared to the Ischemic group, in the diastolic function of the myocardium examined through the minimum rate of change of left ventricular pressure. However, in the Pre group dosed before ischemia and the Pre/Post group dosed both before ischemia and during the reperfusion interval, there was no improvement shown in myocardial function compared to the Ischemic group. Such a result implies that $2 \mu \mathrm{M}$ propofol has a protection function on a reperfusion interval injury than myocardial injury during the ischemic interval. It is estimated that the dosage of propofol before ischemic offsets certain effects of the propofol during reperfusion. Experiments that have shown benign results for myocardial preservation of certain propofol $[5,6]$, were resulted by a higher than clinical concentration dosing capacity right before ischemia or only for a short period during reperfusion. Researchers, including Kokita et al. [5], indicated that 25-50 $\mu \mathrm{M}$ propofol improved 
myocardial function after reperfusion when dosed before ischemia. Researchers, including Ko et al. [6], indicated that $30 \mu \mathrm{M}$ propofol recovered myocardial function, and $100 \mu \mathrm{M}$ propofol reduced the ischemic contraction level. Researchers, including Kawano et al. [14], indicated that in order for propofol to suppress the $\mathrm{K}_{\mathrm{ATP}}$ ion channel and display the myocardial protection effect, a concentration of more than $31 \mu \mathrm{M}$ has to be used and that propofol at less than $2 \mu \mathrm{M}$, which is clinical capacity, did not affect the $\mathrm{K}_{\mathrm{ATP}}$ ion channel. However with the plasma concentration of propofol used clinically being $0.7-20 \mu \mathrm{g} /$ $\mathrm{ml}[9]$, its binding with protein is $97-99 \%$, and the concentration of the free drug that displays the actual effect is $0.006-0.544 \mu \mathrm{g} / \mathrm{ml}$ [15]. Therefore, $2 \mu \mathrm{M}$ propofol $(0.35 \mu \mathrm{g} / \mathrm{ml})$ used in this research is a smaller amount compared to previous research, but it is of huge significance since it has proven the myocardial protection effect after a consistent dosage with clinical concentrations for 120 minutes of reperfusion. There is little research assessing myocardial function during the medication period using propofol at clinical capacity. In conventional research, unlike propofol anesthesia used in clinical cardiac anesthesia, myocardial function has been assessed by dosing before ischemia or during a short period of reperfusion or by dosing concentrated propofol from before ischemia to the whole period of reperfusion. Further research is required in regards to the cause of such differences in the myocardial protection effect, according to the medication period.

ROS mediated path, which was activated during ischemiareperfusion injury, increases changes in gene expression and enzyme system activity and produces cytocaine, which increases cell to adapt to stress, cell proliferation and apoptosis and affects in multiple cell types. This causes protein synthesis by activating cell surface receptors and transcription factor $[3,4]$.

In the case of ischemic preconditioning and inhalation anesthetic, it is reported that action potentials are reduced by hyper polarization of heart membrane through activating $K_{\text {ATP }}$ ion channel of mitochondria and sarcolemma, directly and indirectly towards ischemic-reperfusion injury. This displays myocardial protection effect by suppressing the calcium increase within cells. However, intravenous anesthetics such as propofol are known not to have a myocardial protection effect similar to ischemic preconditioning or inhaled anesthetics [16]. Even so, protection mechanisms of propofol for myocardium occurred during ischemia and reperfusion is still open to dispute. It is considered important because it is an anesthetic often used in cardiac anesthesia.

In this research, the gene expression of Post group had excellent effects in functional recovery of myocardium after ischemia-reperfusion. Unlike the Ischemic group, genes in relation to ion channel, cell defense, cell differentiation and metabolism, which are conflicting aspects, have increased.
Genes in relation to apoptosis, transcriptional regulation, signal transduction and cell movement have reduced, which could be verified in RT-PCR results. While gene expression of Abcc9, Bard1 and Casp4 has increased significantly in the Post group, compared to Ischemic group, gene expression of Lyz, Timp1 and Casp8 has reduced significantly.

The Abcc9 gene is associated with sulfonylurea receptor, which is one of the ATP sensitive potassium channels, similar to the $K_{\text {ATP }}$ ion channel. It has increased 1.5 times more in the Ischemia group than the Post group. The role of the $K_{\text {ATP }}$ ion channel during ischemia-reperfusion injury is known to optimize energy production of mitochondria, to reduce calcium overload, and to have a myocardial protection effect through increasing protein and gene expression that involve in endogenous myocardial cell protection [17]. Therefore, using medication that can open the $\mathrm{K}_{\mathrm{ATP}}$ ion channel for myocardial ischemic injury could possibly be a new therapeutic strategy [18]. Halogenated inhalation anesthetics, such as isoflurane [19], sevoflurane [20], and deflurane [21] during ischemiareperfusion injury, displays myocardial protection by activating the $K_{\text {АTP }}$ ion channel; however, intravenous anesthetic such as propofol are known not to affect $\mathrm{K}_{\mathrm{ATP}}$ ion channel, or to block, dose-dependently, $\mathrm{K}_{\mathrm{ATP}}$ ion channel in higher concentrations [14]. However in this research, $2 \mu \mathrm{M}$ propofol, which is the clinical concentration dosed during reperfusion, has increased in gene expression of the $\mathrm{K}_{\mathrm{ATP}}$ ion channel, displaying different results compared to previous research. Detailed mechanism in regards to such differences in results is unknown, but it is estimated that propofol may control by switching the level of gene expression of the $K_{\text {ATP }}$ ion channel according to its dosage. Further research in relation to this is required.

Reduction in the Lyz gene expression, similar to conventional research results, propofol during ischemia-reperfusion injury is thought to have an effect on myocardial function through reducing formation of ROS and function of neutrophil and through improving metabolic disorders.

Results show that the Casp4 gene, a gene involved in apoptosis, has increased while the Timpl gene and Casp8 genes have decreased. Apoptosis occurs not only from diverse normal physiological stimuli but also from adverse environmental conditions and cytotoxic substances. Recently, apoptosis is known to be a series of processes in relation to genes. Two major paths are involved. Firstly, there is a downstream caspase cascade that occurs with the activation of the Casp9 (caspase-9) gene, an initiator of proteinas through damage of mitochondria [22]. Secondly, there is a path where receptors form groups in a death-receptor path, forming death-inducing signaling complex and finally activating the Casp8 and Casp3 (caspase-3) genes [23]. According to Scarabelli et al. [24], it is proven that apoptosis after ischemia-reperfusion injury is not a simple reaction, 
but is a process that occurrs when the aforementioned paths activate differently. In the case of the Casp8 gene, as it gradually increases from the last half of reperfusion and involves in apoptosis, if the selective inhibitor that targets the Casp8 gene is used, it is said to minimize cell injury. In this research, as for the reduction in the Casp8 gene expression displayed in the Post group compared to the Ischemic group, propofol may have worked as an inhibitor of Casp8 in apoptosis path. However, in the Post group, unlike the Casp8 and the Casp4 gene expression in relation to apoptosis has increased. The functional role of the Casp4 gene in the process of apoptosis during ischemiareperfusion injury is not clearly known. Different results of gene expression of the Casp8 and Casp4 genes are statistically similar; there is not much of a significant difference in the Ischemic group and the Post group. Therefore, it is estimated that propofol has a mediating or controlling function in the apoptosis process during ischemia-reperfusion injury, but it does not have a greater impact.

The Timpl gene is known not only to maintain and control homeostasis and integration of extra-cellular matrix, but it is also known to play an important role in cell growth, apoptosis, and angiogenesis. It protects tissue indirectly by lowering levels of matrix metalloproteinases, which is formulated when stress occurs [25]. However, just like the Casp4 gene, since the difference in two groups is not considerable, it is difficult to conclude that propofol plays an important role for the Timpl gene expression in the ischemia-reperfusion model.

As a limitation of this research, since it is an in vitro experiment done with a Sprague-Dawley rat and a model where ischemic injury has been surgically-created in a normal heart, it can display different results in a heart that has actual ischemic disease. Also, since warm ischemia is maintained at $37^{\circ} \mathrm{C}$, a pH level of 7.4 was used, using Krebs solution and isothermic water bath, variations in perfusion fluid instead of cold ischemia that is used clinically and since the Langendorff model was used, and it does not contain protein and is deprived of neutroghil, humoral hormone or autonomic nervous system effects, it cannot be applied in an actual clinic. Further research targeting in vivo experiments is required. Since this experiment does not quantize protein, which is an end product, but is the research of gene expression involved in every process, there is difficulty in estimating that all genes expressed will compose protein.

In conclusion, in the ischemia-reperfusion model using the Langendorff heart of a Sprague-Dawley rat, $2 \mu \mathrm{M}$ propofol dosed during reperfusion has myocardial protection effect. By observing the effect that propofol has on gene expression through microarray and RT-PCR, gene expression in relation to apoptosis, such as the Casp8 gene, has been reduced. However, it does affect the apoptosis process since there was an increase in expression of the Casp4 gene and reduction in the Timpl gene. It is estimated, however, that one of most probable mechanisms of propofol is the myocardial protection effect mainly through the $\mathrm{K}_{\mathrm{ATP}}$ ion channel rather than the function that suppresses cytotoxicity such as apoptosis. The relevance of the cardio protective effect on the gene, which is involved in $\mathrm{K}_{\mathrm{ATP}}$ ion channel and apoptosis during ischemia-reperfusion injury, is an important outcome of this research. Which exact mechanism is unknown but definitely will help to determine the mechanism for the cardio protective effect of propofol, which is still controversial.

\section{References}

1. Kloner RA, Przyklenk K, Whittaker P. Deleterious effects of oxygen radicals in ischemia/reperfusion. Resolved and unresolved issues. Circulation 1989; 80: 1115-27.

2. Maulik N, Yoshida T, Das DK. Oxidative stress developed during the reperfusion of ischemic myocardium induces apoptosis. Free Radic Biol Med 1998; 24: 869-75.

3. Mittal CK, Murad F. Activation of guanylate cyclase by superoxide dismutase and hydroxyl radical: a physiological regulator of guanosine 3', 5'-monophosphate formation. Proc Natl Acad Sci U S A 1977; 74: 4360-4.

4. Sauer H, Rahimi G, Hescheler J, Wartenberg M. Effects of electrical fields on cardiomyocyte differentiation of embryonic stem cells. J Cell Biochem 1999; 75: 710-23.

5. Kokita N, Hara A, Abiko Y, Arakawa J, Hashizume H, Namiki A. Propofol improves functional and metabolic recovery in ischemic reperfused isolated rat hearts. Anesth Analg 1998; 86: 252-8.

6. Ko SH, Yu CW, Lee SK, Choe H, Chung MJ, Kwak YG, et al. Propofol attenuates ischemia-reperfusion injury in the isolated rat heart. Anesth Analg 1997; 85: 719-24.

7. Murphy PG, Myers DS, Davies MJ, Webster NR, Jones JG. The antioxidant potential of propofol (2,6-diisopropylphenol). Br J Anaesth 1992; 68: 613-8.

8. Kahraman S, Kilinc K, Dal D, Erdem K. Propofol attenuates formation of lipid peroxides in tourniquet-induced ischaemiareperfusion injury. Br J Anaesth 1997; 78: 279-81.

9. Zhou W, Fontenot HJ, Liu S, Kennedy RH. Modulation of cardiac calcium channels by propofol. Anesthesiology 1997; 86: 670-5.

10. Mikawa K, Akamatsu H, Nishina K, Shiga M, Maekawa N, Obara H, et al. Propofol inhibits human neutrophil functions. Anesth Analg 1998; 87: 695-700.

11. Ebel D, Schlack W, Comfere T, Preckel B, Thamer V. Effect of propofol on reperfusion injury after regional ischaemia in the isolated rat heart. Br J Anaesth 1999; 83: 903-8.

12. Onody A, Zvara A, Hackler L Jr, Vigh L, Ferdinandy P, Puskas LG. Effect of classic Preconditioning on the gene expression pattern of rat hearts: a DNA microarray study. FEBS Lett 2003; 536: 35-40.

13. Sergeev P, da Silva R, Lucchinetti E, Zaugg K, Pasch T, Schaub $\mathrm{MC}$, et al. Trigger-dependent gene expression profiles in cardiac Preconditioning: evidence for distinct genetic programs in ischemic and anesthetic preconditioning. Anesthesiology 2004; 100: 474-88.

14. Kawano T, Oshita S, Tsutsumi Y, Tomiyama Y, Kitahata H, Kuroda Y, et al. Clinically relevant concentrations of propofol have no effect 
on adenosine triphosphate-sensitive potassium channels in rat ventricular myocytes. Anesthesiology 2002; 96: 1472-7.

15. Mazoit JX, Samii K. Binding of propofol to blood components. implications for pharmacokinetics and for pharmacodynamics. Br J Clin Pharmacol 1999; 47: 35-42.

16. Zaugg M, Lucchinetti E, Spahn DR, Pasch T, Garcia C, Schaub MC. Differential effects of anesthetics on mitochondrial K (ATP) channel activity and cardiomyocyte protection. Anesthesiology 2002; 97: 1523.

17. Inagaki N, Gonoi T, Seino S. Subunit stoichiometry of the pancreatic beta-cell ATP-sensitive K+ channel. FEBS Lett 1997; 409: 232-6.

18. Mizumura T, Nithipatikom K, Gross GJ. Bimakalim, an ATPsensitive potassium channel opener, mimics the effects of ischemic preconditioning to reduce infarct size, adenosine release, and neutrophil function in dogs. Circulation 1995; 92: 1236-45.

19. Kersten JR, Schmeling TJ, Pagel PS, Gross GJ, Warltier DC. Isoflurane mimics ischemic preconditioning via activation of $\mathrm{K}$ (ATP) channels. reduction of myocardial infarct size with an acute memory phase. Anesthesiology 1997; 87: 361-70.

20. Kersten JR, Schmeling T, Tessmer J, Hettrick DA, Pagel PS, Warltier DC. Sevoflurane selectively increases coronary collateral blood flow independent of $\mathrm{K}_{\mathrm{ATP}}$ channels in vivo. Anesthesiology 1999; 90: 24656.

21. Toller WG, Gross ER, Kersten JR, Pagel PS, Gross GJ, Warltier DC. Sarcolemmal and mitochondrial adenosine triphosphatedependent potassium channels: mechanism of desflurane-induced cardioprotection. Anesthesiology 2000; 92: 1731-9.

22. Hu Y, Benedict MA, Ding L, Nüñz G. Role of cytochrome c and dATP/ATP hydrolysis in Apaf-1-mediated caspase-9 activation and apoptosis. Embo J 1999; 18: 3586-95.

23. Varfolomeev EE, Schuchmann M, Luria V, Chiannilkulchai N, Beckmann JS, Mett IL, et al. Targeted disruption of the mouse Caspase 8 gene ablates cell death induction by the TNF receptors, Fas/Apol, and DR3 and is lethal prenatally. Immunity 1998; 9: 26776.

24. Scarabelli TM, Stephanou A, Pasini E, Comini L, Raddino R, Knight RA, et al. Different signaling pathways induce apoptosis in endothelial cells and cardiac myocytes during ischemia/ reperfusion injury. Circ Res 2002; 90: 745-8.

25. Li YY, Feldman AM, Sun Y, McTiernan CF. Differential expression of tissue inhibitors of metalloproteinases in the failing human heart. Circulation 1998; 98: 1728-34. 